\title{
Dependence and Tolerance in Opioid Abusers
}

\author{
Behzad Saberi* \\ Medical Research, Iran
}

*Corresponding author: Behzad Saberi, Medical Research, Iran.

Received Date: July 03, 2019

Published Date: July 31, 2019

\section{Minireview}

Tolerance to opioids is based on receptor internalization, desensitization and down-regulation. Receptor desensitization is the result of $G$ proteins uncoupling from the receptor due to $\mathrm{b}$-arrestin binding. B-arrestin-2 gene deletion leads to attenuated tolerance to morphine analgesic effects. Decreasing in receptor density leads to down-regulation of the opioid receptor. Dynamin mediates the uncoupled opioid receptors internalization below the surface of the plasma membrane. Dephosphorylation or degradation may be occurred in these receptors [1,2].

Tolerance to opioids can be occurred by different mechanisms. Disparate effects of opioid agonists on some proteins would cause such differences like the opioid agonist's effects on dynamin as a trafficking protein. As examples, down-regulation of receptors of the opioids would be produced by some of them but not with morphine. Internalization of such receptors occurs after long-term administration of etorphine, L-a-acetylmethadol and methadone but does not occur in morphine long-term administration $[3,4]$.

Following acute opioid agonists administration like morphine, the activity of cyclic adenosine monophosphate (cAMP) second messenger pathways, decreases adenylyl cyclase activity inhibition, but following long-term morphine uses, such inhibitory effect would be lost. cAMP pathway activity would rebound following morphine withdrawal. Such activity increasing leads to cAMP response element binding protein phosphorylation enhancement that alters withdrawal related genes transcription in some brain areas $[5,6]$.

Morphine-induced dependence and tolerance can be blocked by N-Methyl-D-Aspartate (NMDA) receptor agonists administration. Protein kinase C-activation by opioids, alters NMDA receptors activity. Protein kinase C phosphorylates the NMDA receptor. Such phosphorylation causes the receptor to be more permeable to calcium. Dextromethorphan as an NMDA antagonist may block the tolerance to morphine during pain treatment. Memantine as another NMDA antagonist can attenuate heroin physical dependency symptoms $[7,8]$.

More studies should be done to find the basic mechanisms involved in opioid dependence and tolerance, so that these findings can lead to choose better treatment options for the relevant patients during clinical practice $[9,10]$.

\section{Acknowledgement}

None.

\section{Conflict of Interest}

No conflict of Interest.

\section{References}

1. Clark MJ, Harrison C, Zhong H, Neubig RR, Traynor JR (2003) Endogenous RGS protein action modulates mu-opioid signaling through Galphao: effects on adenylyl cyclase, extracellular signal-regulated kinases, and intracellular calcium pathways. J Biol Chem 278 (11): 9418-9425.

2. Bohn LM, Gainetdinov RR, Lin FT, Lefkowitz RJ, Caron MG (2000) Muopioid receptor desensitization by betaarrestin- 2 determines morphine tolerance but not dependence. Nature 408 (6813): 720-723.

3. Potenza MN, Gold SJ, Roby-Shemkowitz A, Lerner MR, Nestler EJ (1999) Effects of regulators of $G$ proteinsignaling proteins on the functional response of the mu-opioid receptor in a melanophore-based assay. J Pharmacol Exp Ther 291(2): 482-491.

4. Delfs JM, Zhu Y, Druhan JP, Aston-Jones G (2000) Noradrenaline in the ventral forebrain is critical for opiate withdrawal-induced aversion. Nature 403(6768):430-434.

5. Williams JT, Christie MJ, Manzoni O (2001) Cellular and synaptic adaptations mediating opioid dependence. Physiol Rev 81(1): 299-343.

6. Keith DE, Anton B, Murray SR, Zaki PA, Chu PC, (1998) mu-Opioid receptor internalization: opiate drugs have differential effects on a conserved endocytic mechanism in vitro and in the mammalian brain. Mol Pharmacol 53(3): 377-384.

7. Bisaga A, Comer SD, Ward AS, Popik P, Kleber HD, et al: (2001) The NMDA antagonist memantine attenuates the expression of opioid physical dependence in humans. Psychopharmacology (Berl) 157(1): 1-10.

8. Nestler EJ,Hyman SE, Malenka RC (2001) Molecular Neuropharmacology: A Foundation for Clinical Neuroscience. New York, McGraw Hill. 
9. Chen L, Huang LY (1991) Sustained potentiation of NMDA receptormediated glutamate responses through activation of protein kinase $\mathrm{C}$ by a mu opioid. Neuron 7(3): 319-326.
10. Yabaluri N, Medzihradsky F (1997) Down-regulation of mu-opioid receptor by full but not partial agonists is independent of $\mathrm{G}$ protein coupling. Mol Pharmacol 52(5): 896-902. 